\title{
ECONOMIC IMPACT OF THE US-CHINA TRADE CONFLICT
}

\author{
Jakub Kraciuk ${ }^{1}$, Assoc. Prof. \\ ${ }^{1}$ Faculty of Economic Sciences, Warsaw University of Life Sciences SGGW
}

\begin{abstract}
The trade conflict between the US and China, which started at the beginning of 2018, was the result of the growing imbalance in trade relations between the two countries. The aim of the study was to show the potential effects of this conflict on mutual trade and on the economies of both countries. The 25-point increase in tariff rates on products imported from China, as announced by the US, will reduce imports of Chinese products, which will contribute to a reduction in the US trade deficit. Most of the costs resulting from the imposition of duties will be borne by the Chinese companies, as their profit margins will decrease. Customs receipts can be used to compensate for the social losses of US consumers. However, the losses for China as a result of the introduction of import duties by the USA may be lower if the Chinese decide to take retaliatory action.
\end{abstract}

Key words: US-China foreign trade, trade conflict.

JEL code: F17, F180.

\section{Introduction}

The strategy implemented by Donald Trump since March 2018 to increase pressure on China through the threat of a customs war is aimed at solving the problems that have been growing for years in economic relations with China. From the point of view of the United States, the biggest problems are: China's persistent surplus in trade with the US, restrictions to access to the Chinese market, the undervalued yuan or the lack of sufficient protection of intangible property in China. As a result of actions taken by the United States, at the end of September 2018 the Americans introduced customs duties on nearly 50 \% of products imported from China. In 2019, the Trump administration intends to increase import duties on many Chinese products by 25 percentage points. The US administration's actions meet with the retaliate actions of the Chinese authorities. Therefore, the public debate stresses that the trade conflict not only harms China, but also has negative effects on the American economy.

The aim of the study was to show the potential effects of the trade conflict between the US and China on mutual trade and on the economies of both countries, especially the US economy.

\section{Protectionism and free trade in economic theory and practice}

Throughout the post-war period, as in previous years, we saw two opposing directions of trade policy in the world economy: free trade and protectionism. At that time, both trade policies were present with varying levels of intensity in individual countries. However, the intensification of globalization processes was accompanied by a deepening liberalisation of international exchange (Wrobel, 2013). Economic theory and practice, which point to the advantages of market liberalisation in the process of efficient allocation of resources in the global economy, are still confronted with the instruments of economic protectionism, which is particularly strong in times of the economic downturn. In the economic theory, there is No doubt about the sense of trade liberalisation. Already economics classics, such as A. Smith and D. Ricardo pointed out that if each nation specialises in an area in which it has an absolute or comparative advantage, it can produce more effectively and any obstacles to free trade will significantly reduce these benefits. The theory of economics did not stop at a simple explanation of the benefits of trade by D. Ricardo, referring to natural conditions. Later on, attention was also drawn to the abundance of labour and capital resources held by individual countries. The theory gradually developed, covering, among others, the issues of economies of scale

1 Corresponding author. Phone no. +48 697516711 ; fax: + 48225934028

E-mail address: jakub_kraciuk@sggw.pl 
of production, the network effect (profitability increasing with the growing number of customers), consumer choice, and the creation of a global value chain. The conclusion remained unchanged: the increase in specialization and international exchange leads to an increase in income for all nations participating in these processes (Orlowski, 2016).

The policy of protectionism referring to mercantilism or Keynes' theory is a manifestation of the primacy of national interest in the external actions of states or, in other words, the primacy of the national economy in relation to the world economy. This concept can be defined as striving to develop domestic production, protect the internal market from foreign competition and support own expansion into foreign markets (Kofman, 1992). These objectives are pursued by the state through the means and tools of foreign economic policy, including in particular trade policy. By pursuing a protectionist strategy, the government can also to some extent shape the structure of the economy and foreign trade. If certain domestic industry branches are considered crucial, they obtain preferential treatment and their foreign competitors face duties, limits, regulations, etc. Similarly, in the case of unwanted or irregularly manufactured goods, their imports can be drastically reduced using appropriate protectionist tools. State subsidies or subventions, partly financed e.g. thanks to revenues from customs duties or concessions, may also serve to prevent the problems of high unemployment or low wages, improving the situation of employees and enterprises (Gietkowski Protectionism...).

In the history of the economy, support for free trade and protectionism has changed. In the 19th century, free trade gradually became more and more important, leading to a boom in trade turnover. Rapidly falling transport costs were the main driving force behind the increase in trade exchange. However, nations benefited from this unevenly: while the Western countries gained, and colonial and half- colonized areas were on the loss side, unable to establish an equal competitive struggle mainly due to the unequal political position (Orlowski, 2016). The first half of the 20th century was a period of world wars and crises. During this period, countries tried to save their producers by using the tools of protectionism and suspending currency convertibility. This has led to a significant fall in the value of international trade.

The second half of the 20th century was a period of gradual liberalisation of the world trade as a result of agreements concluded during the GATT negotiating rounds and the creation of integration groups, such as the European Union, NAFTA and MERCOSUR, among others. However, the real triumph of free trade occurred only during the "second wave of globalisation" in the last decades of the 20th century. Communism collapsed, liberal capitalism triumphed, global exports grew rapidly, large companies began to treat the whole world as their market and reach out to consumers all over the world. The progressive process of globalisation has contributed to the rapid development of international trade, the development of the world economy and the economies of many countries. However, the critics of these processes appeared, organized in alter-globalization movements. Some economists are also of the opinion that the principles of the current stage of globalisation have been imposed on the world by the developed countries, especially without taking into account the interests of the developing countries. The criticism of globalisation also comes from a part of Western societies. The relocation of labour-intensive production to developing countries increases the profits of companies, the income of highly skilled workers and lowers prices for consumers. At the same time, it reduces the number of jobs for people with lower qualifications, as a result of which their wages are falling, and the income disparity within societies is increasing (Orlowski, 2016]). This results in 
protests organized in the developed countries and, above all, in France. The change in the United States' foreign economic policy is part of the current processes in many countries around the world.

\section{Trade between the United States and China}

Economic and trade reforms launched in 1979 helped to transform China into one of the world's largest and fastest growing economies. China's economic growth and trade liberalisation, including comprehensive trade commitments made by China following its entry into the World Trade Organisation (WTO) in 2001, led to the rapid development of US-China trade links. The trade between these countries increased sharply after the restoration of diplomatic relations and the signing of the bilateral trade agreement in July 1979. In 1980, total trade between the US and China amounted to approximately USD 4 billion. China was considered the 24th largest trading partner of the United States, the 16th largest export market and the 36th largest source of import. In 2017, total US trade in goods with China amounted to USD 636 billion, making China the largest trading partner of the US (Table 1).

Table 1

US foreign trade with China in the years 1980-2017 in USD billion

Source: U.S. International Trade Commission (USITC) DataWeb

\begin{tabular}{|l|c|c|c|}
\hline Years & Export & Import & Balance \\
\hline $\mathbf{1 9 8 0}$ & 3.8 & 1.1 & 2.7 \\
\hline $\mathbf{1 9 9 0}$ & 4.8 & 15.2 & -10.4 \\
\hline $\mathbf{2 0 0 0}$ & 16.3 & 100.1 & -83.8 \\
\hline $\mathbf{2 0 1 0}$ & 91.9 & 365.0 & -273.0 \\
\hline $\mathbf{2 0 1 1}$ & 104.1 & 399.4 & -295.3 \\
\hline $\mathbf{2 0 1 2}$ & 110.5 & 425.6 & -315.1 \\
\hline $\mathbf{2 0 1 3}$ & 121.7 & 440.4 & -318.7 \\
\hline $\mathbf{2 0 1 4}$ & 123.7 & 468.5 & -344.8 \\
\hline $\mathbf{2 0 1 5}$ & 115.9 & 483.2 & -367.3 \\
\hline $\mathbf{2 0 1 6}$ & 115.6 & 462.6 & -347.0 \\
\hline $\mathbf{2 0 1 7}$ & 130.4 & 505.6 & -375.2 \\
\hline
\end{tabular}

In 2017, China was the third largest export market in the United States, after Canada and Mexico, and by far the first import market (Fig. 1).

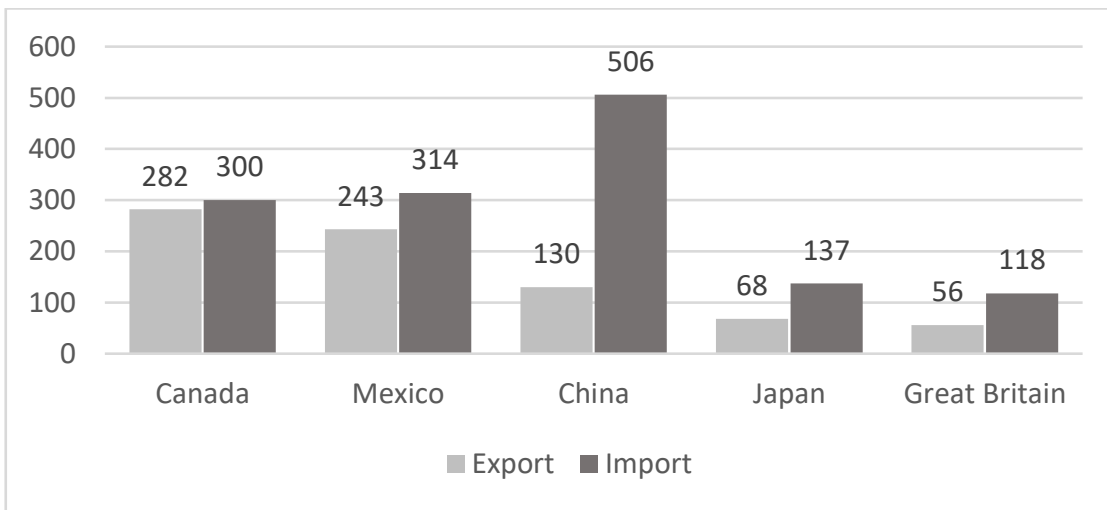

Source: U.S. International Trade Commission (USITC) DataWeb

Fig. 1. US trade turnover with major trading partners in 2017 in USD billions

However, with all these countries, the United States had a negative trade balance in 2017. A record deficit of 376 billion US dollars was noted in trade with China that year. Among the products exported by the US to China in 2017, aviation and space products (mainly civil aircraft and parts), oilseeds (mainly soy beans), motor vehicles, semiconductors and electronic components dominated. 
Americans imported from China mainly communication equipment, computer equipment, various finished goods (such as toys and games), and clothing.

The main problem for many US policymakers is the size of the US trade deficit with China, which rose from USD 10 billion in 1990 to USD 367 billion in 2015. This deficit was reduced to USD 347 billion in 2016, but rose again to USD 375 billion in 2017 (Tab. 1). Over the past few years, the US trade deficit with China has been much larger than with any other trade partner (Morrison, 2018). China's long-standing trade surplus is the result of China's internal economic policy, aimed at providing systemic support to the manufacturing sector. It is based, among other things, on maintaining a fixed exchange rate between the yuan and the US dollar and low interest rates for big business, as well as on many years of halting wage growth. This leads to effective subsidisation of the export sector, which ensures its international competitiveness. US dollar surpluses obtained from exports are invested in the absorptive American capital market, financing American imports from China. In other words, the long-term US trade deficit with China is financed through the import of Chinese capital and rising debt to China. The current economic policy of countries that regularly record surpluses in trade with the USA (apart from China also Germany, Japan, and South Korea) is considered harmful to the American economy, causing a loss of competitiveness and relocation of production from the USA abroad in the actual sphere, and leading to interest rate cuts and the creation of bubbles on asset markets in the financial sphere (Jakobowski, 2018).

Analysts and politicians are therefore of the opinion that the large trade deficits with China indicate that trade relations between these countries are somehow unsustainable, unfair and damaging to the US economy. Others claim that such deficits are largely a reflection of changes in global production and the emergence of extensive and complex supply chains, where China is often the ultimate collection point for export-oriented multinational companies that supply goods from many countries (Morrison, 2018).

\section{The course of the US-China trade conflict}

The US trade deficit with China was the main cause of the trade conflict between the two countries. The US strategy of increasing pressure on Beijing through the threat of a customs war is an evolution in relation to the beginning of Donald Trump's presidency. In 2017, the Americans offered China a form of dialogue aimed primarily at increasing US exports to China and opening up the Chinese market. The result was the signing of agreements for the sale of US products and services worth USD 250 billion and the development of a 100-day plan to open the Chinese market. According to the American side, the Chinese did not fully comply with the agreements, as a result of which from March 2018 onwards Donald Trump adopted a tactic of increasing tension in mutual AmericanChinese relations, threatening to start a customs war (Jakobowski, 2018).

In April 2018, the US government published a list of 1333 Chinese products worth USD 50 billion, on which duties could be imposed. The US Government justified the introduction of customs tariffs with unfair Chinese trade practice, especially in the field of technology transfers and the lack of adequate protection of intellectual property. In response, China submitted in June 2018 a list of US products to be subject to duties. In August this year, both countries introduced customs duties on the products on the lists. The conflict escalated the following month. In September 2018, the US government presented a second list of 6,000 Chinese products with a total value of approximately USD 200 billion, on which duties were to be imposed. At the end of September, the US government began to impose duties on goods on the second customs list. This means that $50 \%$ of Chinese 
imports and $12 \%$ of total US imports are subject to import duties. Initially, it was planned to introduce $10 \%$ tariff rates, but it was decided that in 2019 duties would increase by 25 percentage points (Bown, Kolb, 2018). American-Chinese negotiations at the beginning of 2019 resulted in the US government refraining from increasing tariff rates for the time being. The Chinese authorities did not remain indifferent and decided to retaliate, which resulted in the announcement of the introduction of customs duties and their introduction on 6,000 groups of goods imported from the USA with a total value of USD 60 billion (We are facing an escalation...). It seems, however, that the ongoing negotiations, resulting, among other things, in the suspension of the US Government's increase in tariff rates on trade with China, as well as China's agreement to support US exports and measures aimed at reducing inequalities in mutual trade, have increased the chances of concluding an agreement. On the other hand, a country that wins a trade war may not be interested in ending it.

\section{Economic and social consequences of the US-China trade war}

A direct symptom of the trade conflict between the United States and China has been the raising of existing tariff rates or the introduction of new tariff rates in trade between the two countries. In the absence of an agreement and the pessimistic scenario, tariff rates on US imports from China may increase to $27.5 \%$ in 2019 , because some products had already been subject to customs duties. However, most of the products imported from China were not subject to tariff rates, and in their case the tariff rates may increase from zero to $25 \%$.

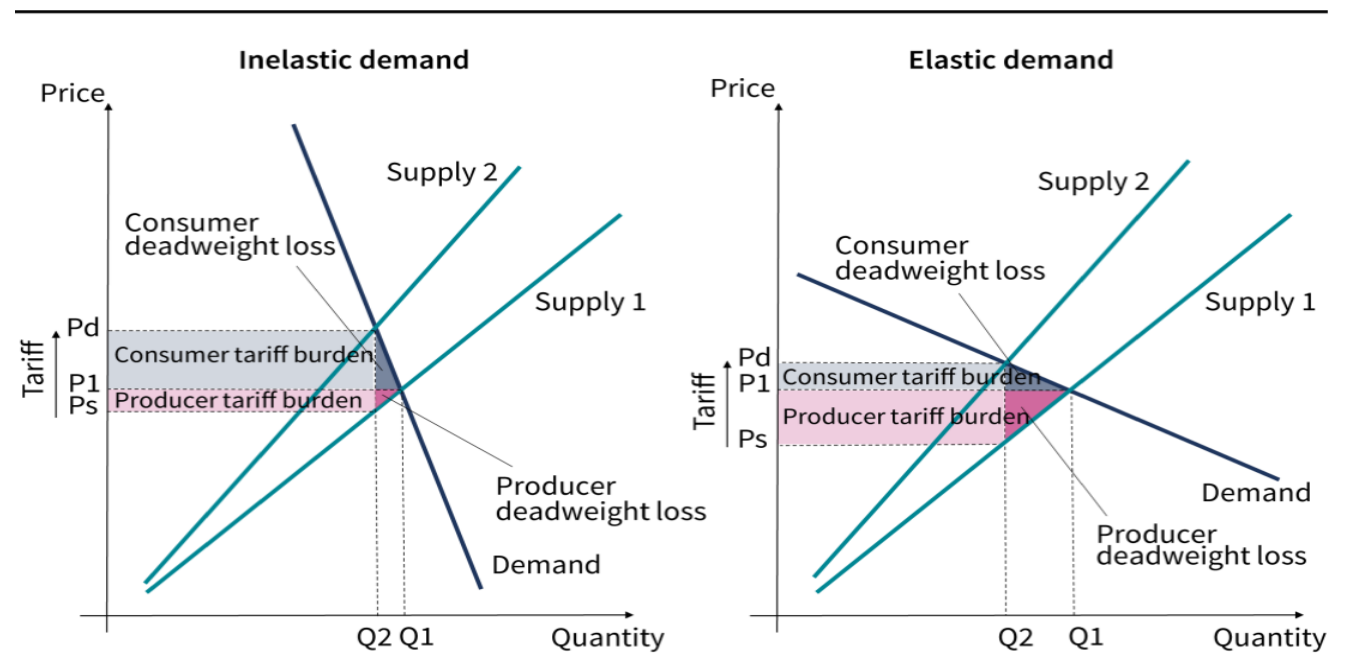

Source: G. Felbermayr, B. Zoller-Rydzek, Who is Paying for the Trade War with China?, EconPol Policy Brief $11 / 2018$

Fig. 2. Tariff incidence on a partial market without domestic supply

Such a situation may concern the vast majority of consumer goods and semi-finished products. The introduction of such high duties would have a negative impact mainly on companies importing and using semi-finished products from China for production in the US. US import duties will increase the prices of Chinese products and reduce profit margins for Chinese companies. As a result, vulnerable Chinese companies may limit production and exports to the US market. This raises the question of whether US companies will be able to adapt their supply chains and fill the supply gap that might arise, or whether the effect will be an increase in the prices of Chinese products in the US. In such case, both US companies and consumers will be affected. If the response of consumers to price increases is weaker than that of producers, customs tariffs will first and foremost result in the increase in consumer price. Otherwise, the producer price will initially decrease, for example 
because companies will give up their margins. This effect is mainly related to the availability of substitute goods on the market. Figure 2 shows the effect of introducing a duty in a sub-balance market where there are No direct domestic competitors. In the absence of a duty, supply balances with demand at price P1 and quantity Q1. Producer and consumer prices are identical. An import duty of e.g. $25 \%$ is a wedge between the consumer price Pn and the price Pa that producers receive. With inelastic demand, the volume of goods sold decreases slightly, the producer price decreases slightly, and the consumer price increases significantly. If demand is elastic, consumer prices increase, leading to a significant reduction in demand. At the same time, producer prices are falling sharply. In both cases, the duties in place distort the decisions of consumers and suppliers. The degree of distortion depends on the evolution of supply, the evolution of price (duty amount) and relative price flexibility. Due to the increase in domestic commodity prices, consumption is declining, resulting in a loss of welfare for consumers and producers. The US Secretary of the Treasury will receive duty revenue of $(\mathrm{Pn}-\mathrm{Pa}) \mathrm{Q} 2$, but only part of the cost (Pn-P1) Q2 is borne by domestic consumers. The remaining part ( $\mathrm{P} 1-\mathrm{Pa}) \mathrm{Q} 2$ is a transfer of Chinese producers to the US government. Whether the introduced duty reduces or increases welfare (here: consumer pension plus the customs revenue of the state) depends on whether the transfer from abroad exceeds the losses caused by a drop in consumption or not (Broda, Limao, Weinstein, 2008).

After an increase in import duties by 25 percentage points

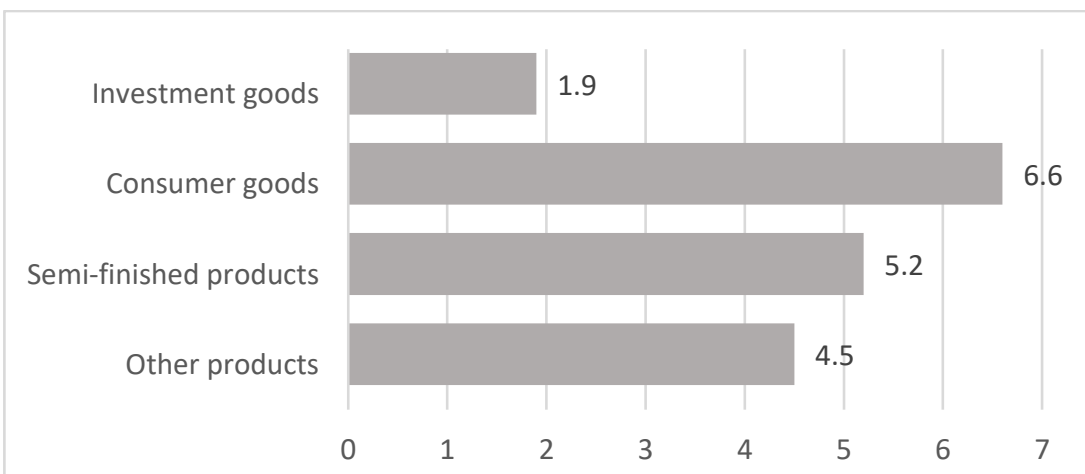

Source: G. Felbermayr, B. Zoller-Rydzek, Wer bezahlt Trumps Handelskrieg mit China? ifo Schnelldienst $22 / 2018$

Fig. 3. Average price increase for American consumers (percentage points)

Figure 3 shows the expected average price increase of Chinese imports for consumers in four categories. By far the highest price increase caused by the introduction of import duty would occur in the case of consumer goods, it would be slightly lower in the case of semi-finished products and by far the lowest for investment goods. Thus, households with the lowest incomes will be most affected by the increase in consumer goods prices because they spend a significant part of these incomes on purchasing cheap Chinese products (Felbermayr, Zoller-Rydzek, 2018). Import duties will therefore lead to a relatively greater decrease in real income of these households.

Figure 4 shows the price development of Chinese producers' products due to the US import duties. If import duties were increased by 25 percentage points, the average price would fall by more than 20 percentage points. The biggest price decrease would occur in the case of investment products.

After an increase in import duties by 25 percentage points 


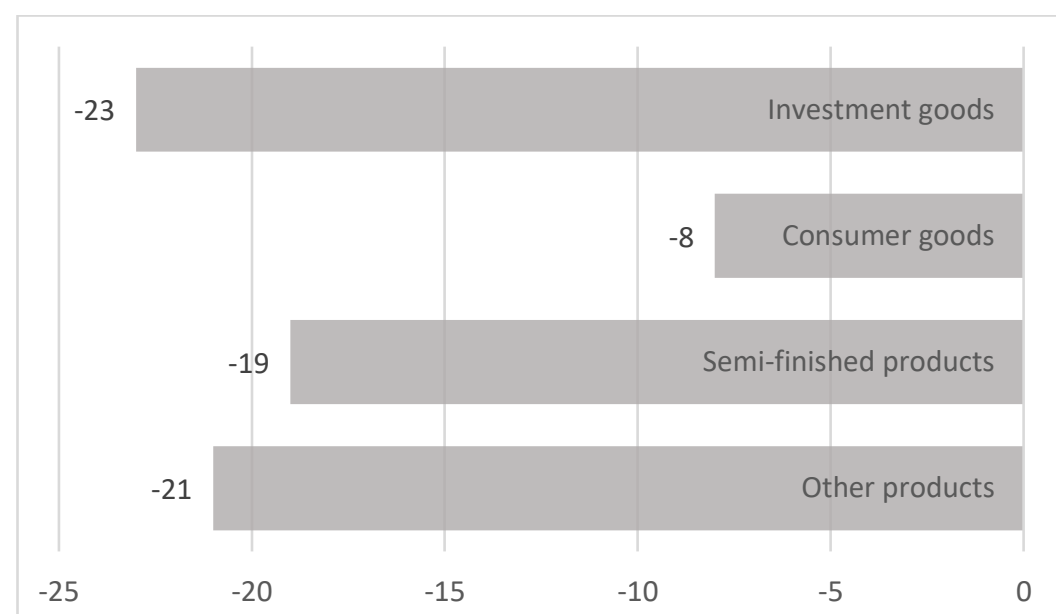

Source: G. Felbermayr, B. Zoller-Rydzek, Wer bezahlt Trumps Handelskrieg mit China? ifo Schnelldienst 22/2018

Fig. 4. Average decrease in Chinese producer prices (percentage points)

Such a significant reduction in prices may cause many Chinese companies to withdraw from the US market. Felbermayr and Zoller-Rydzek (2018) in their analyses indicate that an increase in tariff rates for Chinese products by 25 percentage points will result in a 37 percentage point decrease in imports of Chinese products on average, including a decrease in consumer goods by more than 40 percentage points and in investment good by around 28 percentage points, which will contribute to a USD 63 billion decrease in the US trade deficit. This will be the case if the US-Chinese trade is not affected by other factors, especially China's retaliatory actions, which can certainly be expected.

The total economic effect of the possible introduction of US import duties on Chinese products can be defined as the total of the surface areas of two triangles indicating the social losses of producers and consumers (Fig. 2.). Total social losses in China and the US amount to approx. USD 1.6 billion. About one third, or USD 522 million, of these losses are borne by US consumers, while the rest of the losses are borne by Chinese companies exporting their products to the United States. In order to assess the overall economic effect of the introduction of duties, the potential revenue from the duties introduced should also be taken into account. Most of the costs resulting from the imposition of duties will be borne by the Chinese companies, as their profit margins will decrease. Customs receipts can be used to compensate for the social losses of US consumers. As a result, the revenues from customs duties that President Trump may introduce amount to USD 22.5 billion, of which USD 18.9 billion is to be paid by Chinese companies. This represents a net increase in prosperity for the US economy of USD 18.4 billion (Felbermayr and Zoller-Rydzek, 2018).

\section{Summary}

The trade conflict between the US and China is now entering a decisive stage. It is difficult to predict whether the negotiations between the US and Chinese administrations will halt this conflict, or whether the Americans will increase import duties on Chinese products by the planned 25 percentage points. Should this happen, the US Government, through a strategic choice of Chinese products, especially those with elastic demand, will not only minimise the negative effects of price increases on US consumers and companies, but will also contribute to significant net welfare gains in the US. However, consideration should be given to the possibility of China introducing trade retaliation, which is acute for the US. The situation in the United States is also complicated by China's current position in global value chains, particularly in high-tech industries. The Chinese factories manufacture computers, electronic and telecommunication equipment of all major global manufacturers. The imposition of duties will result in a loss of competitiveness for US technology 
companies (losing access to the manufacturing base in China), as well as destabilising the economies of US allies in East Asia.

\section{References}

1. Bown, C., Kolb, M., (2018). Trump's Trade Wars Timeline: An Up-to-date Guide. The Peterson Institute for International Economics, https://piie.com/system/files/documents/trump-trade-war-timeline.pdf. Access:29.12.2018.

2. Broda, C., N. Limao und D. Weinstein (2008). Optimal Tariffs. The Evidence American Economic Review 98(5), pp. 2032-2335.

3. Czeka nas eskalacja konfliktu miedzy USA a Chinami? (Does an escalation of the conflict between the USA and China await us?) https://strefabiznesu.pl/czeka-nas-eskalacja-konfliktu-miedzy-usa-achinami/ar/13739992 Access: 03.01.2019.

4. Felbermayr, G. Zoller-Rydzek, B. (2018). Wer bezahlt Trumps Handelskrieg mit China? ifo Schnelldienst No. 22. pp. 30-35.

5. Felbermayr, G., Zoller-Rydzek, B. (2018). Who is Paying for the Trade War with China?, EconPol Policy Brief No. 11, p.3.

6. Gietkowski, P., Protekcjonizm a wolny handel (Protectionism and free trade), http://mme.sknfm.pl/protekcjonizm-a-wolny-handel/ Access: 03.01.2019.

7. Jakobowski, J. (2018). Konflikt handlowy USA-Chiny. Etap drugi, Komentarze (US-China trade conflict. Stage Two, Comments), the Marek Karp Centre for Eastern Studies in Warsaw, No. 277, pp.2-3.

8. Kofman, J. (1992). Nacjonalizm gospodarczy - szansa czy bariera rozwoju (Economic nationalism development opportunity or barier). Wydawnictwo Naukowe PWN, Warsaw, p. 99.

9. Morrison, W. M. (2018). China-U.S. Trade Issues, Congressional Research Service, Washington, pp. 8-10.

10. Orlowski, W. M., Wolny handel: Roosevelt kontra Trump, (Free Trade: Roosevelt versus Trump), https://www.nbp.pl/edukacja/dodatki_educational_2016/rot/slow_handel_all_do_konta_polityka_20_26.04. 2016.pdf Access:06.01.2019.

11. Stokes, B. (2018). Americans, Like Many in Other Advanced Economies, Not Convinced of Trade's Benefits, PEW Institute, http://www.pewglobal.org/2018/09/26/americans-like-many- in-other-advanced-economiesnot-convinced-of-trades-benefits/.

12. Wrobel, A. (2013). Liberalizacja i protekcjonizm w polityce panstwa - przyklad sektora rolnego, (Liberalisation and protectionism in state policy - an example of the agricultural sector), Faculty Scientific Journals of the University of Economics in Katowice. Economic Studies No. 139. 